\title{
Testing the ecomorphological hypothesis in a headwater riffles fish assemblage of the rio São Francisco, southeastern Brazil
}

\author{
Lilian Casatti* and Ricardo M. C. Castro**
}

The ecomorphology of 14 fish species resident in a headwater riffles area of the São Francisco river, southeastern Brasil, was analyzed and combined with diet and feeding behavior data, previously obtained by us. The three larger species groups formed in the ecomorphological analysis were found to reflect primarily microhabitat occupation in the following manner: a) nektonic characids with compressed bodies, lateral eyes and lateral pectoral fins, with diurnal and opportunistic feeding habits (Astyanax rivularis, Bryconamericus stramineus, and Bryconamericus sp.); b) nektobenthic characiforms and siluriforms with fusiform bodies and expanded pectoral fins, including sit-and-wait characidiins, predators of aquatic insect larvae (Characidium fasciatum and Ch. zebra), as well as the algae grazing parodontids (Apareiodon ibitiensis and Parodon hilarii), and also the heptapterid and trichomycterid catfishes that practice substrate speculation and feed on benthic aquatic insect larvae (Cetopsorhamdia iheringi, Imparfinis minutus, Rhamdia quelen, and Trichomycterus sp.); c) benthic species with depressed bodies, suctorial oral discs, dorsal eyes, and horizontal pectoral fins, represented by the periphytivorous loricariid catfishes (Hisonotus sp., Harttia sp., and Hypostomus garmani). Correlation between diet and general morphology was not significant in our analysis, unless when the analyzed set included only nektonic and benthic species, indicating that the lack of correlation between these factors is most pronounced in the group of nektobenthic species. The unequivocal case of morphological convergence found between the nektobenthic Characidiinae and Parodontidae is a clear example of the integration between phylogenetic information and ecomorphology, and provides a way to objectively identify cases of morphological and adaptive convergence and divergence. Furthermore, the general congruence between the ecomorphological results and the independently obtained ecological data about the analyzed fish species in their natural environment seems to be strong evidence in favor of the proposed predictive capabilities of the ecomorphological hypothesis.

A ecomorfologia de 14 espécies de peixes residentes em um trecho de corredeiras do curso superior do rio São Francisco, sudeste do Brasil, foi analisada e combinada com dados de comportamento alimentar e dieta, previamente obtidos por nós. Os três principais agrupamentos ecomorfológicos de espécies identificados refletem a ocupação espacial de micro-hábitats da seguinte forma: a) caracídeos nectônicos com corpos comprimidos, olhos laterais e nadadeiras peitorais laterais, com hábitos noturnos e oportunistas alimentares (Astyanax rivularis, Bryconamericus stramineus e Bryconamericus $\mathrm{sp}$.); b) nectobentônicos com corpos fusiformes e nadadeiras peitorais expandidas, que incluem os caracidíneos predadores de espreita que se alimentam principalmente de larvas aquáticas bentônicas de insetos (Characidium fasciatum e Characidium zebra), parodontídeos pastadores de epilíton (Apareiodon ibitiensis e Parodon hilarii) e bagres especuladores de substratos que se alimentam principalmente de larvas aquáticas de insetos (Cetopsorhamdia iheringi, Imparfinis minutus, Rhamdia quelen e Trichomycterus sp.); c) bentônicos com corpos deprimidos, lábios modificados em discos orais suctorias, olhos dorsais e nadadeiras peitorais amplas, representados pelos cascudos perifitívoros (Hisonotus sp., Harttia sp. e Hypostomus garmani). Correlação entre dieta e morfologia geral não foi significative em nossa análise, a não ser quando o conjunto analisado incluiu apenas as espécies nectônicas e bentônicas, indicando que a ausência de correlação entre esses fatores é mais pronunciada no grupo de espécies nectobentônicas. A constatação do caso ineqüívoco de convergência morfológica entre os Characidiinae e Parodontidae nectobentônicos é um claro exemplo de como a integração da informação filogenética com a ecomorfologia pode identificar objetivamente casos de convergência e divergência adaptativa. Finalmente, a congruência entre os resultados ecomorfológicos com aqueles obtidos independentemente sobre a ecologia das espécies estudadas em seu ambiente natural parece ser uma forte evidência em favor do proposto valor preditivo da hipótese ecomorfológica.

Key words: Fish community, Feeding tactics, Diet, Morphology, Rheophilic, Phylogeny.

*UNESP - Universidade Estadual Paulista, Laboratório de Ictiologia, Departamento de Zoologia e Botânica - IBILCE, Rua Cristóvão Colombo, 2265, 15054-000 São José do Rio Preto, SP, Brazil. e-mail: lcasatti@ibilce.unesp.br

**Laboratório de Ictiologia de Ribeirão Preto (LIRP), Departamento de Biologia, FFCLRP-USP, Av. Bandeirantes, 3900, 14040-901

Ribeirão Preto, SP, Brazil. e-mail: rmcastro@ffclrp.usp.br 


\section{Introduction}

In lotic systems, riffles are habitats characterized by strong currents, turbulent water flow, rocky substrates and relatively high gas exchange rates with the atmosphere (Hynes, 1970; Allan, 1995). The interplay between currents and rocky substrates usually generates areas rich in food, such as patches of rapidly growing periphytic algae and the aquatic insect larvae that directly or indirectly fed on them, as well as many areas of shelter among the coarse sand, gravel and rocks that make up the substrate. Thus, the relative ample and sustained food offer and abundance of shelters in the study area are probably the main environmental factors allowing, in an adaptive and evolutionary sense, the formation of a fish community characterized by a high proportion of species showing uniquely derived structures and behaviors to live successfully in fast flowing waters (Casatti \& Castro, 1998).

Several studies about fish morphology and ecology were generally based on the ecomorphological paradigm (e.g., Gatz, 1979a,b; Mahon, 1984; Watson \& Balon, 1984; Balon et al., 1986; Wikramanayake, 1990; Winemiller, 1991; Douglas \& Matthews, 1992; Motta \& Kotrschal, 1992; Beaumord \& Petrere, 1994; Motta et al., 1995; Mullaney Jr. \& Gale, 1996; Piet, 1998), which explains the morphological differences among species as the result of different selective pressures (Beaumord \& Petrere, 1994).

In our study site, a riffles stretch in the upper course of the rio São Francisco, southeastern Brazil, all the resident fish species - which are the subject of this study - dealt with the unyielding problem of moving and maintaining their spatial positions in a strong current without a prohibitive energy expenditure by means of morphological (e.g., presence of adhesive suctorial structures and flattened bodies) and/or behavioral adaptations (e.g., preferentially living in lenthic water areas at the bottom) (Casatti \& Castro, 1998).

Although an ecomorphological analysis aims to find the relationship between morphology and ecology at the levels of individuals, populations, guilds, and communities (Peres-Neto, 1999), studies that integrate natural history and ecomorphological data on their analyses are rare (but see Winemiller, 1991). Furthermore, when dealing with communities, the application of the ecomorphological analytical method is supposedly especially valuable due to its power to objectively identify cases of adaptive convergence between species that are not closely related phylogenetically (Karr \& James, 1975), as well as identify cases of adaptive divergence between phylogenetically closely related taxa, as long there are available phylogenies for the studied species (Reilly \& Wainwright, 1994).

Thus, in this study, we aimed to investigate the level of congruence between ecomorphological patterns and the ecologies of the components of a fish assemblage studied directly in its natural habitat. Consequently, the results of our ecomorphological analysis were contrasted with the ones we obtained previously about the spatial distribution, period of activity, feeding behavior, and diet of this fish assemblage (Casatti \& Castro, 1998).
We believe that the present study offers an extremely favorable scenario to test the predictive values of the ecomorphology hypothesis, since we not only independently obtained detailed ecological information of the studied species in their natural habitat to compare with the ecomorphological results, but also because the studied fish assemblage is clearly and predominantly structured by the elevated water current velocity, an environmental factor of relatively easy detection and measurement. Additionally, since there are available recent phylogenetic hypotheses for most of the studied taxa (see Malabarba et al., 1998), it was possible to objectively detect cases of adaptive convergence between species not closely related phylogenetically and evolutionary divergence between phylogenetically closely related species.

\section{Material and Methods}

Field work was carried out in an approximately $60 \mathrm{~m}$ stretch of the upper rio São Francisco (20 $\left.30^{\circ} \mathrm{S} 46^{\circ} 50^{\prime} \mathrm{W}\right)$, municipality of São Roque de Minas in the State of Minas Gerais, southeastern Brazil (Fig. 1) (see map with study site location in Casatti \& Castro, 1998: 230, Fig. 1). During the study period the current ranged from 0.3 to $2.3 \mathrm{~m}_{\mathrm{s}} \mathrm{s}^{-1}$, discharge from 1.8 to $3.2 \mathrm{~m}^{3} \cdot \mathrm{s}^{-1}$, air temperature from 10 to $31.5^{\circ} \mathrm{C}$, water temperature from 12.4 to $23^{\circ} \mathrm{C}$ and dissolved oxygen from 8.9 to $21.7 \mathrm{mg} . \mathrm{l}^{-}$ ${ }^{1}$ (dry and rainy seasons, respectively). The methods used for fish underwater observation and collection, and diet analysis, are described in Casatti \& Castro (1998).

To perform the ecomorphological analyses, measurements were taken on four to 11 adult individuals of each resident fish species (Table 1$)$ using a caliper $(0.1 \mathrm{~mm}$ precision $)$, and the resulting measurements were used to calculate 14 eco-

Table 1. Fish species resident in the studied upper rio São Francisco riffles, southeastern Brazil.

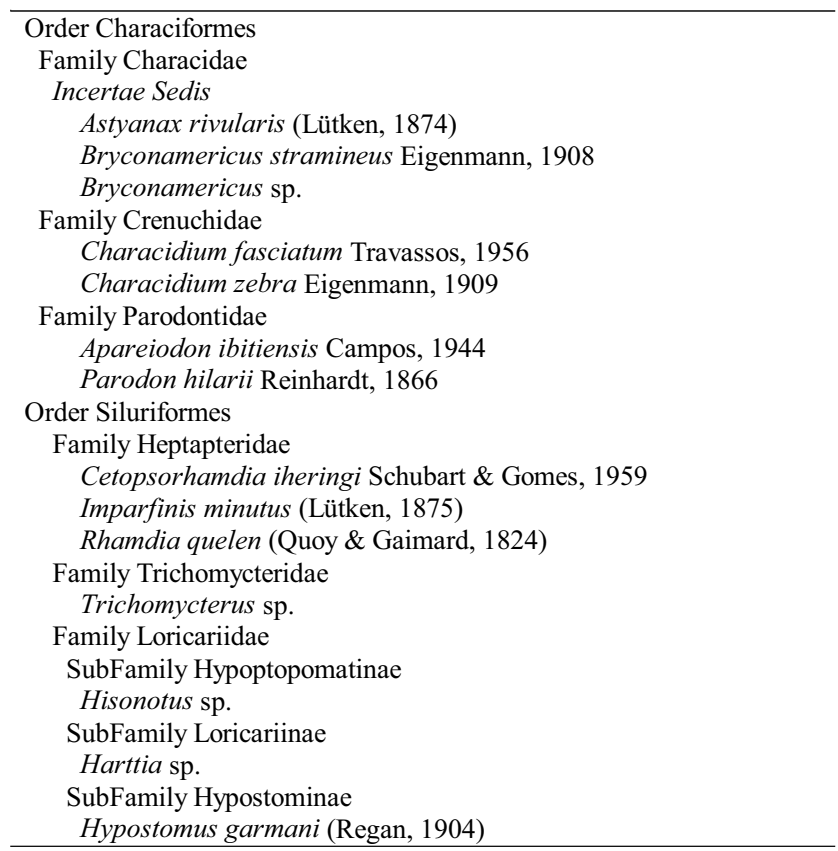


morphological attributes. Fin areas were estimated from their contour outlined on millimetric graph paper (Beaumord \& Petrere, 1994). Based on Gatz (1979a), Mahon (1984), and Watson \& Balon (1984) we selected the 13 ecomorphological attributes described below, along with the relative area of dorsal fin; which we propose here as an additional ecomorphological attribute for fishes.

1) Compression index: maximum body depth divided by maximum body width (called flatness by Gatz, 1979a). High values may indicate a laterally compressed fish, inhabiting lenthic habitats (Watson \& Balon, 1984).

2) Relative depth: maximum body depth divided by standard length (Gatz, 1979a). Lower values would indicate fishes inhabiting fast waters, and they are directly related to their capacity for making vertical turns (Gatz, 1979a).

3) Relative caudal peduncle length: caudal peduncle length divided by the standard length (Gatz, 1979a). Long peduncles indicate fishes inhabiting turbulent waters and with good swimming ability (Watson \& Balon, 1984).

4) Caudal peduncle compression index: caudal peduncle depth divided by the caudal peduncle width (Gatz, 1979a). High values indicate compressed peduncles, which are typical of less active swimmers (Gatz, 1979a).

5) Index of ventral flattening: maximum midline (a straightline from the middle of the posterior edge of the hypural bones along the body side to the most anterior point of the head) depth divided by maximum body depth (Mahon, 1984; Watson \& Balon, 1984). Low values indicate fishes inhabiting environments with high hydrodinamism, able to maintain their spatial position even when stationary (Hora, 1930).

6) Relative area of dorsal fin: dorsal fin area divided by the body area. The dorsal fin is mainly a stabilizing plane, functioning also as a rudder; dorsal fins with relatively small areas may, as a general rule, be expected to function more efficiently in fast flowing waters (Gosline, 1971).

7) Relative area of pectoral fin: pectoral fin area divided by body area (Gatz, 1979a). High values indicate slow swimmers which use pectoral fins to perform maneuvers and breakings, or fishes inhabiting fast waters which use them as airfoils to deflect the water current upwards and thereby maintain themselves firmly attached to the substrate (Mahon, 1984; Watson \& Balon, 1984).

8) Pectoral fin aspect ratio: maximum length of pectoral fin divided by its maximum width (Gatz, 1979a). High values indicate long fins, typical of fishes that swim for long distances (Mahon, 1984; Watson \& Balon, 1984), or pelagic fishes that swim constantly.

9) Relative area of caudal fin: caudal fin area divided by the body area (Mahon, 1984; Watson \& Balon, 1984). High values indicate caudal fins able to produce great and rapid thrusts, necessary for the typical swimming mode of many benthic fishes (Webb, 1977).

10) Relative head length: head length divided by the standard length (Gatz, 1979a). High values may indicate fishes able to feed on relatively larger preys (Gatz, 1979a).

11) Relative eye position: depth of the eye midline divided by the head depth (Mahon, 1984; Watson \& Balon, 1984). Position of eyes is assumed to be related to vertical habitat preference (Gatz, 1979a). High values indicate dorsally located eyes, typical of benthic fishes (Mahon, 1984; Watson \& Balon, 1984).

12) Relative mouth width: mouth width divided by standard length (Gatz, 1979a). High values indicate fishes able to feed on relatively large preys (Gatz, 1979a).

13) Relative mouth height: mouth height divided by standard length (Gatz, 1979a). High values may also indicate fishes able to feed on relatively large prey (Gatz, 1979a).

14) Mouth orientation: defined by the angle formed between the tangential plane to both lips and the perpendicular plane to the longitudinal axis of the body when the mouth is open (Gatz, 1979a) (values in degrees were converted to decimal scale). High values indicate benthophagic species (Gatz, 1979a).

To ordinate species in the ecomorphological space a principal component analysis (PCA) was performed using a covariance matrix with the mean values of the 14 attributes of the 14 resident fish species, using the software PC-Ord version 4 (McCune \& Mefford, 1999). To decide which components (axes) were retained for interpretation, broken-stick eigenvalues were compared to actual eigenvalues for each axis; all axes with eigenvalues greater than the broken-stick eigenvalues were selected for interpretation (McCune \& Mefford, 1999). A cluster analysis was performed to group the fish species according to their ecomorphological similarity using the Pearson correlation coefficient and UPGMA grouping, processed with the software NTSYS 2.1 (Rohlf, 2000). Subsequently, we calculated the cophenetic coefficient, using a standard routine of the same software. The terms nektonic, nektobenthic, and benthic follow the definitions of Lincoln et al. (1995). To identify the ecomorphological variables that best discriminated among habitat-use guilds (nektonic, nektobenthic and benthic), a Canonical Discriminant Analysis (CDA) was performed. The CDA is a method of linear modeling which first tests for differences in variables (ecomorphological attributes) among the predefined groups (guilds). If differences are found, the next step is to find the linear combinations (discriminant functions) of the variables that best discriminate among groups. In the present study a 0.001 tolerance was chosen and Stepwise Backward Automatic Estimation was selected among Systat 10 software options. Backward stepwise begins with all variables in the model, irrespective of the entry criteria, and all variables with the lowest F-to-remove value below the remove limit (default as 3.9) are excluded from the model.

The null hypothesis which assumes no significative correlation between diet (with food items grouped ecologically) and morphology was evaluated applying the Mantel test (Mantel, 1967). Diet similarity matrix (based on Casatti \& Castro, 1998) was computed by Bray-Curtis similarity coefficient, and the morphological information by Pearson correlation, with 5,000 permutations tested. To test the phylogeny effect in the correlation between diet and morphology (Dou- 
Table 2. Mean (M) and standard deviation (SD) values for the 14 ecomorphological attributes calculated for the fish species resident in the studied upper rio São Francisco riffles, southeastern Brazil. CI, compression index; RD, relative depth; RPL, relative caudal peduncle length; $\mathrm{CPC}$, caudal peduncle compression index; IVF, index of ventral flattening; RAD, relative area of dorsal fin; RAP, relative area of pectoral fin; PAR, pectoral fin aspect ratio; RAC, relative area of caudal fin; RHL, relative head length; REP, relative eye position; RMW, relative mouth width; RMH, relative mouth height; OB, mouth orientation.

\begin{tabular}{|c|c|c|c|c|c|c|c|c|c|c|c|c|c|c|c|}
\hline Species & & $\mathrm{CI}$ & $\mathrm{RD}$ & RPL & $\mathrm{CPC}$ & IVF & RAD & RAP & PAR & RAC & RHL & REP & RMW & $\mathrm{RMH}$ & $\mathrm{MO}$ \\
\hline \multirow[t]{2}{*}{ Astyanax rivularis } & $\mathrm{M}$ & 1.86 & 0.30 & 0.14 & 2.23 & 0.55 & 0.05 & 0.03 & 1.64 & 0.15 & 0.26 & 0.66 & 0.08 & 0.04 & 1.45 \\
\hline & SD & 0.10 & 0.01 & 0.01 & 0.38 & 0.04 & 0.01 & 0.01 & 0.24 & 0.01 & 0.01 & 0.06 & 0.01 & 0.01 & $<0.01$ \\
\hline \multirow[t]{2}{*}{ Bryconamericus stramineus } & $\mathrm{M}$ & 1.67 & 0.21 & 0.10 & 2.02 & 0.57 & 0.04 & 0.04 & 2.13 & 0.14 & 0.22 & 0.70 & 0.05 & 0.03 & 1.26 \\
\hline & SD & 0.23 & 0.01 & 0.01 & 0.15 & 0.05 & 0.01 & 0.01 & 0.38 & 0.02 & 0.01 & 0.03 & 0.01 & 0.01 & $<0.01$ \\
\hline \multirow[t]{2}{*}{ Bryconamericus sp. } & $\mathrm{M}$ & 1.71 & 0.26 & 0.16 & 2.42 & 0.53 & 0.05 & 0.05 & 1.87 & 0.13 & 0.27 & 0.68 & 0.06 & 0.03 & 1.74 \\
\hline & SD & 0.10 & 0.01 & 0.02 & 0.28 & 0.03 & 0.01 & 0.01 & 0.31 & 0.03 & 0.01 & 0.07 & 0.01 & 0.01 & $<0.01$ \\
\hline \multirow[t]{2}{*}{ Characidium fasciatum } & $\mathrm{M}$ & 1.41 & 0.21 & 0.21 & 3.26 & 0.51 & 0.12 & 0.12 & 2.09 & 0.14 & 0.26 & 0.79 & 0.03 & 0.02 & 3.00 \\
\hline & SD & 0.08 & 0.01 & 0.09 & 0.36 & 0.04 & 0.02 & 0.02 & 0.30 & 0.01 & 0.01 & 0.06 & 0.01 & 0.01 & $<0.01$ \\
\hline \multirow[t]{2}{*}{ Characidium zebra } & $\mathrm{M}$ & 1.47 & 0.22 & 0.15 & 2.77 & 0.49 & 0.07 & 0.08 & 2.14 & 0.11 & 0.23 & 0.80 & 0.02 & 0.02 & 1.98 \\
\hline & SD & 0.08 & 0.03 & 0.02 & 0.35 & 0.02 & 0.01 & 0.01 & 0.19 & 0.02 & 0.01 & 0.08 & 0.00 & 0.01 & $<0.01$ \\
\hline \multirow[t]{2}{*}{ Apareiodon ibitiensis } & $\mathrm{M}$ & 1.35 & 0.21 & 0.15 & 2.71 & 0.45 & 0.06 & 0.09 & 1.72 & 0.13 & 0.20 & 0.71 & 0.03 & 0.01 & 2.41 \\
\hline & SD & 0.06 & 0.02 & 0.02 & 0.51 & 0.02 & 0.01 & 0.02 & 0.20 & 0.02 & 0.01 & 0.06 & 0.01 & 0.00 & $<0.01$ \\
\hline \multirow[t]{2}{*}{ Parodon hilarii } & M & 1.44 & 0.24 & 0.15 & 3.23 & 0.49 & 0.04 & 0.06 & 1.47 & 0.14 & 0.21 & 0.78 & 0.03 & 0.02 & 2.20 \\
\hline & SD & 0.07 & 0.02 & 0.02 & 0.40 & 0.02 & 0.00 & 0.01 & 0.17 & 0.02 & 0.01 & 0.19 & 0.01 & 0.00 & $<0.01$ \\
\hline \multirow[t]{2}{*}{ Cetopsorhamdia iheringi } & $\mathrm{M}$ & 0.97 & 0.17 & 0.16 & 2.19 & 0.59 & 0.10 & 0.09 & 1.16 & 0.22 & 0.24 & 0.91 & 0.08 & 0.04 & 2.06 \\
\hline & SD & 0.05 & 0.01 & 0.01 & 0.57 & 0.02 & 0.02 & 0.02 & 0.12 & 0.03 & 0.01 & 0.07 & 0.01 & 0.01 & $<0.01$ \\
\hline \multirow[t]{2}{*}{ Imparfinis minutus } & $\mathrm{M}$ & 0.69 & 0.12 & 0.19 & 2.22 & 0.55 & 0.15 & 0.13 & 0.86 & 0.26 & 0.22 & 0.76 & 0.09 & 0.05 & 2.24 \\
\hline & SD & 0.07 & 0.01 & 0.03 & 0.14 & 0.05 & 0.02 & 0.02 & 0.18 & 0.02 & 0.02 & 0.06 & 0.01 & 0.01 & $<0.01$ \\
\hline \multirow[t]{2}{*}{ Rhamdia quelen } & $\mathrm{M}$ & 1.09 & 0.19 & 0.17 & 3.75 & 0.48 & 0.10 & 0.05 & 1.50 & 0.16 & 0.25 & 0.85 & 0.11 & 0.03 & 1.99 \\
\hline & SD & 0.10 & 0.01 & 0.01 & 0.99 & 0.05 & 0.02 & 0.01 & 0.14 & 0.03 & 0.01 & 0.08 & 0.01 & 0.01 & $<0.01$ \\
\hline \multirow[t]{2}{*}{ Trichomycterus sp. } & M & 1.16 & 0.16 & 0.20 & 3.87 & 0.49 & 0.07 & 0.07 & 1.15 & 0.13 & 0.20 & 0.99 & 0.08 & 0.02 & 2.04 \\
\hline & SD & 0.13 & 0.02 & 0.02 & 0.59 & 0.07 & 0.01 & 0.01 & 0.19 & 0.05 & 0.01 & 0.02 & 0.01 & 0.01 & $<0.01$ \\
\hline \multirow[t]{2}{*}{ Hisonotus sp. } & $\mathrm{M}$ & 0.73 & 0.16 & 0.34 & 1.52 & 0.39 & 0.11 & 0.09 & 1.68 & 0.19 & 0.24 & 0.71 & 0.07 & 0.04 & 3.14 \\
\hline & SD & 0.04 & 0.01 & 0.01 & 0.24 & 0.05 & 0.02 & 0.01 & 0.17 & 0.03 & 0.01 & 0.07 & 0.01 & 0.01 & $<0.01$ \\
\hline \multirow[t]{2}{*}{ Harttia sp. } & $\mathrm{M}$ & 0.60 & 0.15 & 0.40 & 0.50 & 0.25 & 0.13 & 0.14 & 1.52 & 0.13 & 0.21 & 0.86 & 0.12 & 0.05 & 3.14 \\
\hline & SD & 0.05 & 0.01 & 0.01 & 0.04 & 0.04 & 0.05 & 0.07 & 0.17 & 0.02 & 0.01 & 0.06 & 0.01 & 0.00 & $<0.01$ \\
\hline \multirow[t]{2}{*}{ Hypostomus garmani } & $\mathrm{M}$ & 0.66 & 0.19 & 0.30 & 1.02 & 0.35 & 0.21 & 0.15 & 1.51 & 0.30 & 0.23 & 0.85 & 0.12 & 0.07 & 3.14 \\
\hline & SD & 0.06 & 0.02 & 0.02 & 0.18 & 0.04 & 0.04 & 0.03 & 0.20 & 0.04 & 0.04 & 0.07 & 0.01 & 0.01 & $<0.01$ \\
\hline
\end{tabular}

glas \& Matthews, 1992; Hugueny \& Pouilly, 1999) a Mantel test was also carried out. For this, the same diet similarity matrix mentioned before was compared to a taxonomic distance matrix which was constructed following the methodology of Douglas \& Matthews (1992), in which a value of 1 was coded for congeneric species-pairs, of 2 for species-pair belonging to different genera within the same family, of 3 for species-pairs belonging to different families within the same order, and of 4 for species-pairs belonging to different orders. Voucher specimens are deposited in the fish collection of the Museu de Zoologia da Universidade de São Paulo (MZUSP 50734-50752).

\section{Results}

Mean values and standard deviations for each attribute are shown in Table 2. The two first axis were retained for interpretation due to eigenvalues values higher than the broken-stick eigenvalues (Table 3). The first component (PC 1) explained $72 \%$ of the variance (Table 3 ) and the main attribute in this axis was the caudal peduncle compression index, discriminating species with compressed caudal peduncles (Characiformes, Heptapteridae, and Trichomycteridae) from species with relatively more depressed caudal peduncles (Loricariidae) (Fig. 2).

The second component (PC 2) explained $20 \%$ of the variance, adding to $92 \%$ of cumulative variance in the two first axes (Table 3). The most important attributes to this component with positive loadings were the compression index and the pectoral fin aspect ratio, which discriminated species with compressed bodies and pectoral fins longer than wider (Characidae) from species with relatively more depressed bodies and pectoral fins wider than longer (Parodontidae, Heptapteridae, Trichomycteridae, and Loricariidae) (Fig. 2). The most important attribute to this negative loading component was mouth orientation, discriminating species with ventral and subterminal mouths (Parodontidae, Heptapteridae, Trichomycteridae, and Loricariidae) from those with terminal mouths (Characidae) (Fig. 2).

Canonical Discriminant Analysis showed that the mean values for attributes were different $(p=0.0004)$ among those habitat-use guilds identified by cluster analysis (Fig. 3). The relative importance of attributes included in the model calculated by F-statistics is presented in Table 4 . The least important attributes for discriminating among the studied species are (in decreasing order of usefulness) the attributes "relative area of dorsal fin", "relative eye position", "relative mouth width", "relative mouth height", and "mouth orientation". On the other hand, the most usefull (also in decreasing order of usefulness) were the attributes "compression index", "caudal peduncle compression index" and "pectoral fin aspect ratio". The first eigenvalue (535.57) found is higher than the second (195.97), indicating that the first canonical variable 
captured most of the differences among groups, representing $73 \%$ of the total dispersion of the groups.

When the overall results of the ecomorphological analysis were examined in light of the species feeding biology, there is not a significant correlation between diet and mor-

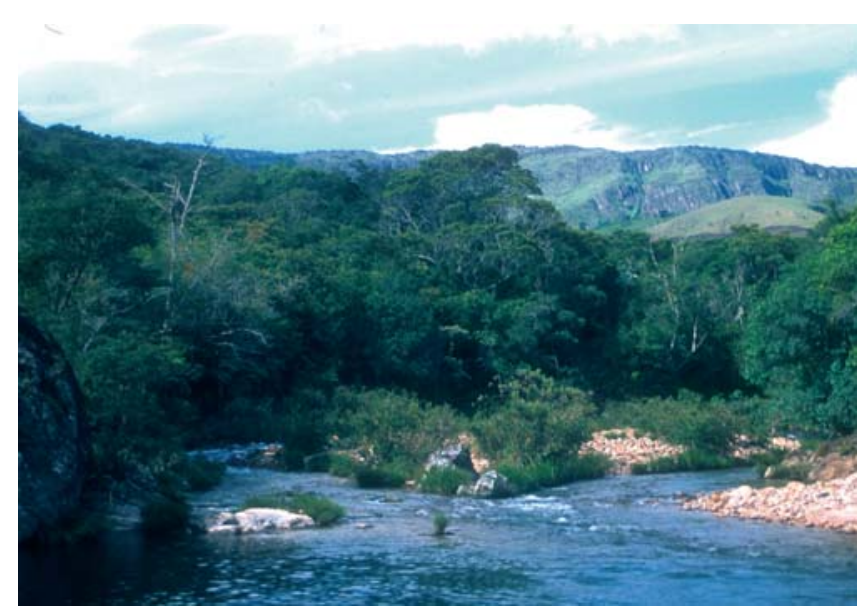

Fig. 1. General view of the studied riffle stretch $\left(20^{\circ} 30^{\prime} \mathrm{S}\right.$ $\left.46^{\circ} 50^{\prime} \mathrm{W}\right)$ in the upper rio São Francisco, southeastern Brazil (photo: Ricardo M.C. Castro).
Table 3. Loading and correlation values of the 14 ecomorphological attributes in the two axis, with the first axis representing the principal component 1 (PC1) and the second axis the principal component 2 (PC2), calculated for the fish species resident in the studied upper rio São Francisco riffles, southeastern Brazil.

\begin{tabular}{lcccc}
\hline & \multicolumn{3}{c}{ PC1 } & \multicolumn{2}{c}{ PC2 } \\
\cline { 2 - 6 } Attributes & Loadings & Correlations & Loadings & Correlations \\
\hline Compression index & 0.26 & -0.68 & 0.48 & 0.66 \\
Relative depth & 0.02 & -0.41 & 0.05 & 0.62 \\
Relative caudal peduncle & -0.06 & 0.80 & -0.06 & -0.38 \\
length & & & & \\
Caudal peduncle & 0.86 & -0.96 & -0.48 & -0.28 \\
compression index & & -0.69 & 0.06 & 0.34 \\
Index of ventral flattening & 0.06 & -0.64 & -0.03 & -0.39 \\
Relative area of dorsal fin & -0.03 & 0.64 & -0.35 \\
Relative area of pectoral fin & -0.02 & 0.68 & -0.02 & 0.66 \\
Pectoral fin aspect ratio & 0.04 & -0.14 & 0.40 & -0.27 \\
Relative area of caudal fin & -0.02 & 0.50 & -0.03 & 0.37 \\
Relative head length & 0.01 & -0.18 & 0.01 & -0.68 \\
Relative eye position & 0.01 & -0.01 & -0.11 & -0.28 \\
Relative mouth width & -0.02 & 0.54 & -0.07 & -0.07 \\
Relative mouth height & -0.01 & 0.83 & 0.01 & -0.57 \\
Mouth orientation & -0.42 & 0.77 & -0.60 & - \\
\hline Variance explained (\%) & 72 & - & 20 & \multicolumn{2}{c}{4.221} \\
\hline Eigenvalues & \multicolumn{3}{c}{15.159} & \multicolumn{3}{c}{3.380} \\
\hline Broken-stick eigenvalues & \multicolumn{3}{c}{4.881} &
\end{tabular}

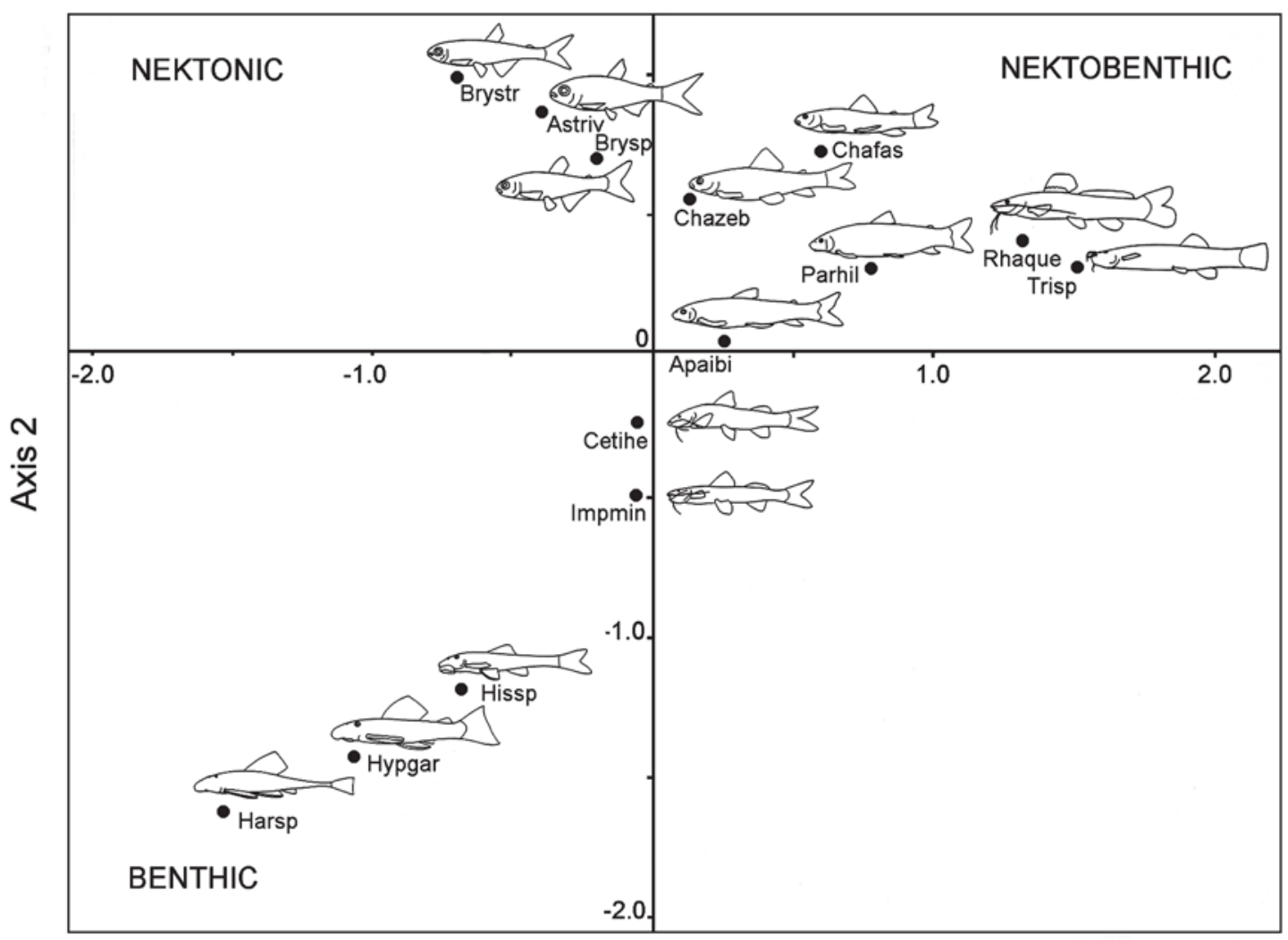

Axis 1

Fig. 2. Projection of the two first principal components of the 14 resident fish species in the upper rio São Francisco studied riffles, southeastern Brazil: Astriv, Astyanax rivularis; Brystr, Bryconamericus stramineus; Brysp, Bryconamericus sp.; Chafas, Characidium fasciatum; Chazeb, Characidium zebra; Apaibi, Apareiodon ibitiensis; Parhil, Parodon hilarii; Cetihe, Cetopsorhamdia iheringi; Impmin, Imparfinis minutus; Rhaque, Rhamdia quelen; Trisp, Trichomycterus sp.; Hissp, Hisonotus sp.; Hypgar, Hypostomus garmani; Harsp, Harttia sp. 


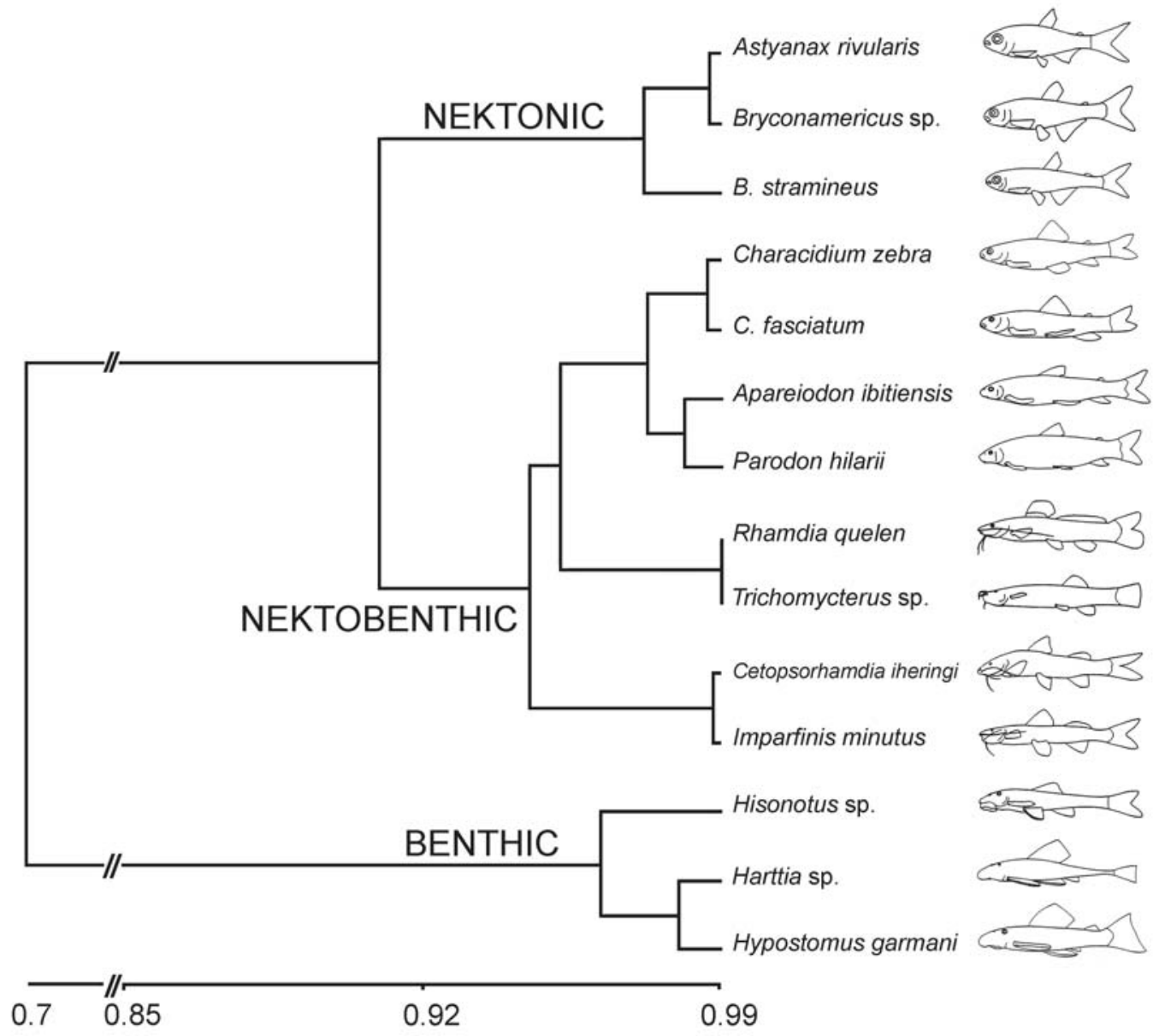

Fig. 3. Dendrogram of ecomorphological relationships of the 14 resident fish species in the upper rio São Francisco studied riffles, southeastern Brazil.

phology $(r=-0.1083, p>0.05)$, unless nektobenthic species are excluded. In this more restrict analysis, diet and morphology did show significant correlation for the smaller group encompassing only the nektonic and benthic species $(\mathrm{r}=$ $0.8894, \mathrm{p}<0.05)$, pointing out that correlation between diet and morphology is low for the group of nektobenthic species. Mantel comparisons between diet and taxonomic matrices revealed a non-significant correlation when all species were considered jointly $(\mathrm{r}=0.18, \mathrm{p}>0.05)$. Notwithstanding, a marginal significant correlation $(\mathrm{r}=-0.88, \mathrm{p}=0.09)$ was found when nektonic and benthic species were tested together and separately from the nektobenthic ones. When the last group of species was analized alone, a non-significant correlation was found $(r=0.0008, p>0.05)$.

\section{Discussion}

According to the ecomorphological hypothesis, the ecomorphological attributes of each species should reflect important features of its ecology and should therefore be indicative of its habits and adaptations to different habitats (Gatz, 1979b; Mahon, 1984; Watson \& Balon, 1984). In our study, the most significant ecomorphological attributes to ordinate the species in the morphospace were those related to locomotion and feeding capabilities, such as the body compression index, the caudal peduncle compression index, the position of the eyes, and the orientation of the mouth. Since our study was not restricted to an ecomorphological analysis but also included independently obtained ecological data, from here on our discussion aims to integrate, as proposed by Reilly \& Wainwright (1994: 347), the ecomorphological groups (Fig. 3) with pertinent aspects of their biologies studied (Casatti \& Castro, 1998). In addition, making use of the recently available synthesis on phylogeny and classification of Neotropical fishes (Malabarba et al., 1998; Reis et al., 2003), we tried whenever possible to describe possible historical patterns of ecomorphological relationships.

Nektonic species: A. rivularis, Bryconamericus sp. and $B$. stramineus

This group contains the so-called tetra species, belonging to the Characidae family. The Characidae family has its monophyly yet to be truly tested (see Weitzman \& Malabarba, 1998), although the taxa contained in our group were recently 
considered by Malabarba \& Weitzman (2003), based on the synapomorphic presence in adult male specimens of bony hooks on fin rays and the lack of a supraorbital bone, part of a tentatively proposed monophyletic group of "characids". Unfortunately, the three taxa in our study are far from having their phylogenetic relationships clarified and, consequently, were considered by Lima et al. (2003) part of very large assemblage of genera incertae sedis in Characidae (along with approximately $65 \%$ of the almost 1.000 species of Characidae recognized in Reis et al., 2003). One of the main reasons why the genera Astyanax and Bryconamericus are not yet clearly positioned phylogenetically is their clear lack of obvious morphological phylogenetically informative characters, such as can be found in other Characiformes such as the eversiblemouthed, detritus-eating prochilodontids (see Castro \& Vari, 2003, 2004). All Astyanax and Bryconamericus species show a generalized ostariophysian "tetra" appearance (see Fink \& Fink, 1981), associated with almost continuous swimming in various parts of the water column, such as laterally compressed bodies, eyes laterally positioned on the head, small dorsal fins and small and relatively elongated pectoral fins. Thus, none of the studied species show obvious morphological adaptations to live in the fast flowing water environment studied by us. Notwithstanding, they deal with the current mostly through behavioral strategies, chiefly among them the habit of swimming downriver from larger rocks (Bryconamericus sp.), near the river margins (A. rivularis) and also near the surface (B. stramineus), all being microhabitats where current speed is significantly lower (see Casatti \& Castro, 1998) and the energy expenditure by the individual to stay in place consequently is also significantly lower.

Although the monophyly of the genera Astyanax and Bryconamericus - both very speciose, with at least 86 and 51 valid species respectively according to Lima et al. (2003) - is far from being established, it is noteworthy that in the dendrogram of ecomorphological relationships (see Fig. 3) Bryconamericus sp. is in a group with A. rivularis, and not with its congener $B$. stramineus. We believe that this is most probably due to the fact that $B$. stramineus spent almost all day just under the riffles mid channel water surface, whereas $A$. rivularis and Bryconamericus sp. spent the daytime exploring the whole depth of the water column - mostly at the margins and downstream from larger rocks (Casatti \& Castro, 1998). If indeed the genera in question happen to be monophyletic, the discussed grouping is clearly a case where the different ecological requirements prevailed, especially those concerning the swimming abilities of B. stramineus and Bryconamericus sp., over the morphological phylogenetic signal.

As to be expected, their generalized feeding apparatus allows them to have a very generalized and opportunistic diet, feeding on aquatic insect larvae, algae, terrestrial insects and plants, obtained through a varied number of feeding tactics, of which collecting items carried by the current and at the water surface are the most important ones. It is noteworthy that collecting food items at the water surface was the sole observed feeding tactic of $B$. stramineus, an- other probable explanation for its lone position inside the nektonic group.

Nektobenthic species: C. fasciatum, C. zebra, A. ibitiensis, P. hilarii, C. iheringi, I. minutus, R. quelen and Trichomycterus sp.

In this group the subsets (Fig. 3) almost exactly reflect the known phylogenetic relationships of its components: all the Siluriformes are in a subset, and all Characiformes are in another. Furthermore, the characiforms are neatly split between the monophyletic taxa Characidiinae (C. zebra and $C$. fasciatum) and Parodontidae (A. ibitiensis and P. hilarii) (see Buckup, 1998), whereas the siluriforms are split in a monophyletic unit formed by the Heptapteridae $C$. iheringi and $I$. minutus (see Bockmann, 1998: 482, fig. 11; Bockmann \& Guazzelli, 2003) and the non-monophyletic group containing the heptapterid $R$. quelen and the trichomycterid Trichomycterus sp. (see Bockmann \& Guazzelli, 2003; de Pinna, 1998). The Characidiinae are not phylogenetically closely related to the Parodontidae within the characiforms (Fig. 4), as is also the case for the Heptapteridae and Trichomycteridae within the siluriforms (see de Pinna, 1998). Notwithstanding their phylogenetic relationships, all species in this group possess a general body morphology that allows them to swim near the bottom to explore the two most abundant food resources in the riffles: periphyton growing on rocks and aquatic insect larvae.

Although not sister-taxa, the Characidiinae and Parodontidae were closer to each other ecomorphologically than to any other taxa. The monophyletic Characidiinae (with at least 47 valid species in Characidum) occur in different habitats, from small lowland streams to waterfalls, but most are inhabitants of fast flowing small streams (Buckup, 1993, 2003), where they most probably feed almost exclusively on aquatic benthic arthropods. The equally monophyletic Parodontidae (with 10 valid species both in Apareiodon and Parodon) are reophilic and usually found in fast flowing bodies of water up to 1.000 meters in altitude, where they use their well developed paired fins to attach themselves temporarily to the rocky bottom from were they scrape algae using their specialized jaws and teeth (Roberts, 1974; Pavanelli, 2003). Both the Characidiinae and Parodontidae posses fusiform bodies, large and horizontally positioned paired fins and relatively small mouths. Clearly this is a case of similar morphologies independently acquired, since they are in different major characiform clades, the Crenuchoidea and Parodontoidea, respectively (see Buckup, 1998).

In the study site the characidiins and parodontids are both diurnal and the former feed on aquatic insect larvae caught using the sit-and-wait predation tactic (Fig. 5), whereas the latter are exclusive periphyton grazers (Fig. 6) (Casatti \& Castro, 1998). Our results concerning both taxa are clearly an example of ecomorphological convergence between not closely related taxa, as reported by Cody \& Mooney (1978), Motta \& Kotrschal (1992), Winemiller et al. (1995) and Motta et al. (1995) for other vertebrate groups. 


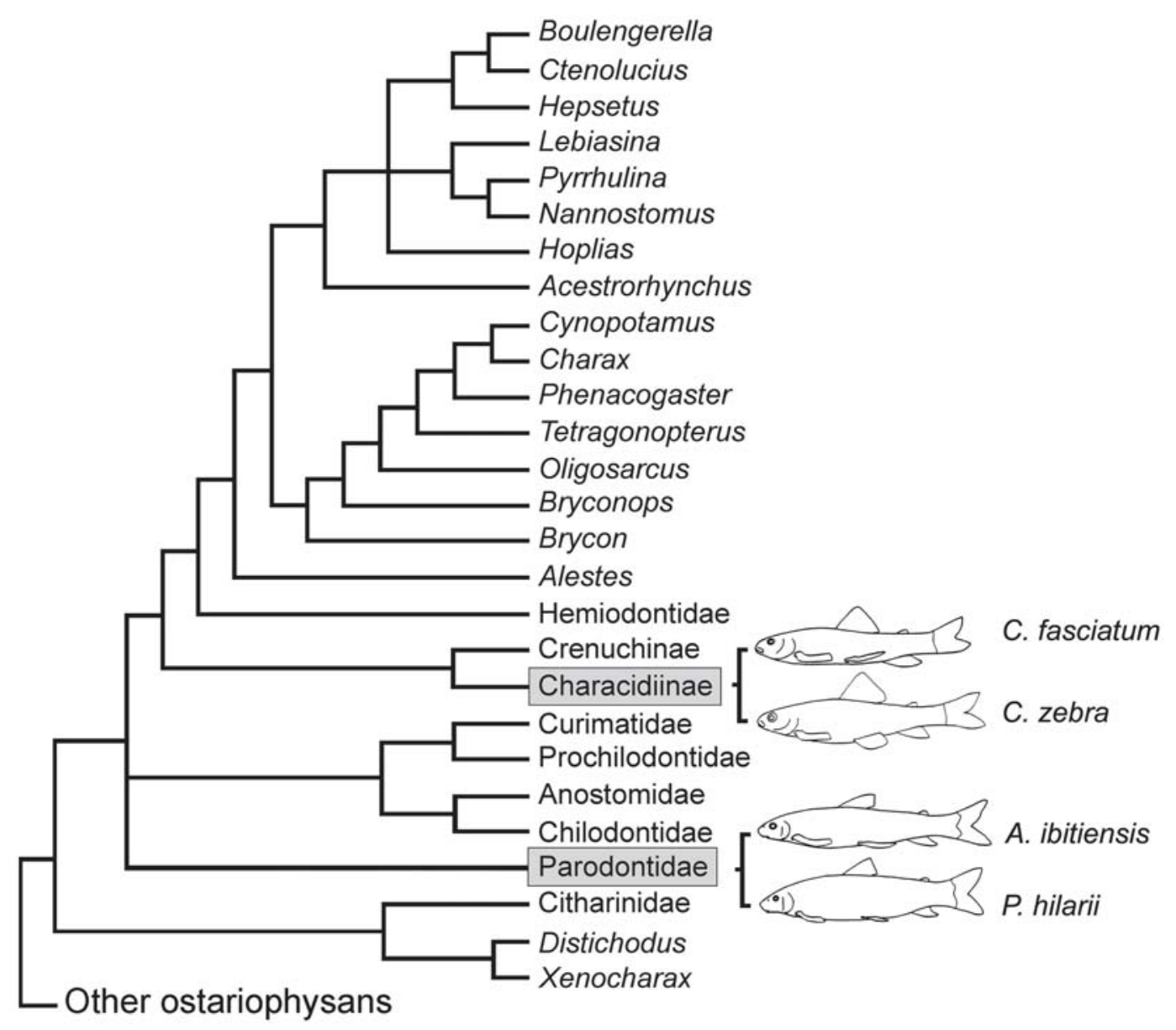

Fig. 4. Cladogram of phylogenetic relationships among selected characiform fishes (modified from Buckup, 1998: 134), showing the phylogenetic position of the studied Characidiinae and Parodontidae species, an example of ecomorphological adaptive convergence in the studied riffles.

The Heptapteridae (with 186 valid species) and the Trichomycteridae (with 171 valid species) are two relatively large families of catfishes (see Reis et al., 2003), and as a rule possess relatively slender and elongate bodies, well developed sensory barbels and dorsally located eyes. These are features that allow them to successfully explore the small spaces between rocks (see Fig. 7) where they feed mostly on aquatic insect larvae, usually hunted while inspecting the substrate with their mouths and sensory barbels, although large specimens of Rhamdia can be found feeding mainly on fishes and terrestrial insects (Casatti \& Castro, 1998). Both C. iheringi and I. minutus share extremely low pectoral fin aspect ratios, indicating that both species are not constant and long distance swimmers (see Mahon, 1984; Watson \& Balon, 1984). Both $R$. quelen and Trichomycterus sp. possess extremely compressed caudal peduncles, which is considered an ecomorphological attribute of less active swimmers (Gatz, 1979a). This is in accordance with our observations (Casatti \& Castro, 1998) that both species, differently from $C$. iheringi and $I$. minutus, occupy the more marginal and sluggish flowing areas of the riffles, and were not common near the faster flowing mid channel area.
Benthic species: Hisonotus sp. (= Microlepidogaster sp. in Casatti \& Castro, 1998), Harttia sp. and H. garmani

This group is composed exclusively by members of the monophyletic family Loricariidae, the world's largest family of Siluriformes, with at least 683 valid species (de Pinna, 1998; Reis et al., 2003). The group as a whole is highly specialized morphologically, with sucker mouths and scraping teeth (de Pinna, 1998; Armbruster, 2004). Many of the morphological traits of the Loricariidae are known to be related to life spent in fast flowing waters, such as their depressed bodies, greatly expanded and horizontally oriented paired fins, and suctorial oral discs (see Hynes, 1970; Vogel, 1981). All species in this group fed on periphyton (mostly algae) scraped from the surface of bottom rocks (H. garmani and Harttia sp.) or from the surface of submerged branches, leaves and roots of the marginal vegetation (Hisonotus sp.) (Casatti \& Castro, 1998). Hypostomus garmani is part of the large (about 170 valid species) and phylogenetically problematic subfamily Hypostominae (de Pinna, 1998; Weber, 2003), whereas Harttia sp. and Hisonotus sp., are members of the well supported monophyletic subfamilies Loricariinae (209 valid species) and Hypoptopomatinae (79 valid species), respectively (de Pinna, 


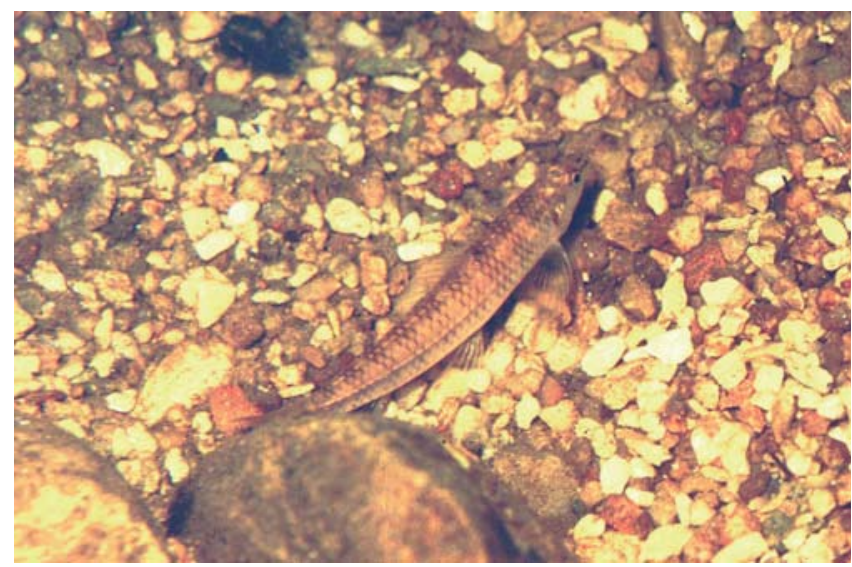

Fig. 5. Characidium zebra specimen using its expanded and horizontally orientated paired fins to hold its position against the current in the riffles substrate, during daytime (photo: Ricardo M.C. Castro).

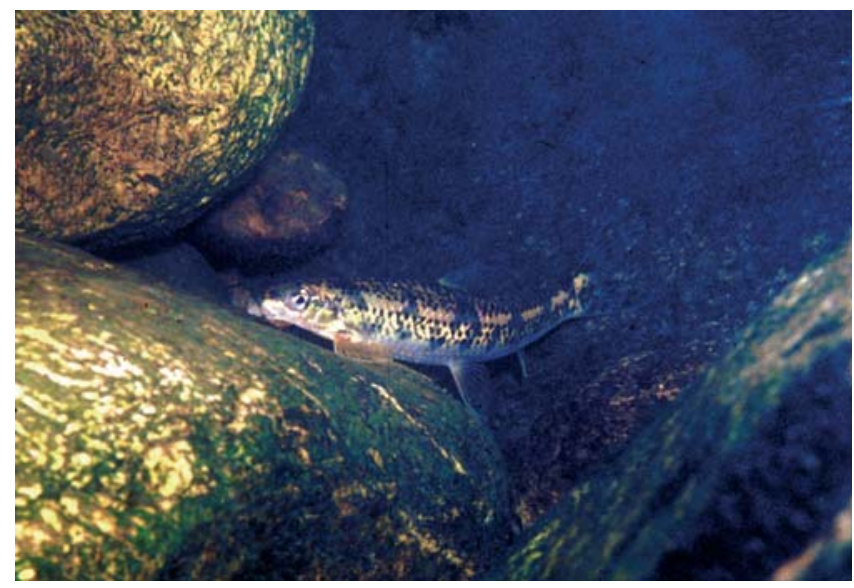

Fig. 6. Apareiodon ibitiensis specimen using its expanded and horizontally orientated paired fins to hold its position over a rocky surface while grazing on periphyton in the riffles substrate, during daytime (photo: Ricardo M.C. Castro).

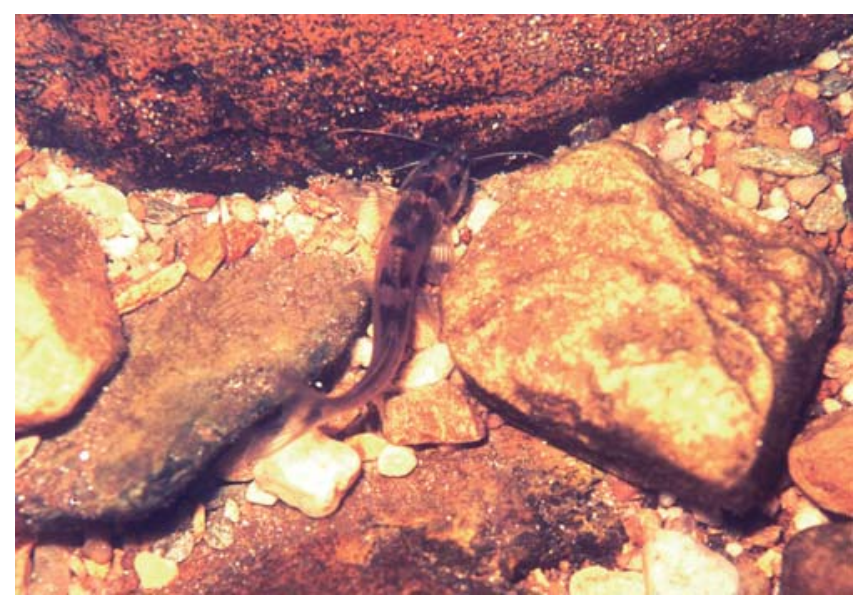

Fig. 7. Imparfinis minutus specimen sheltering itself from current among rocks in the riffles bottom, during daytime (photo: Ricardo M.C. Castro).
Table 4. F-values and tolerance values used to establish the relative importance of the attributes included in the discriminant model, along with the respective coefficients expressing the correlation between each original variable and two canonical discriminant functions (DF), standardized by within variances. Dashes (-) represent variables excluded from the model due to a combination of a low F-value (below 3.9) with a high tolerance value (above 0.001).

\begin{tabular}{lcccc}
\hline Attributes & F-values & Tolerance & DF1 & DF2 \\
\hline Compression index & 44.6 & 0.001 & 9.237 & 23.430 \\
Relative depth & 25.0 & 0.001 & -8.479 & -17.914 \\
Relative caudal peduncle lengt & 25.2 & 0.016 & -7.234 & 1.018 \\
Caudal peduncle compression & 38.1 & 0.025 & -0.078 & -5.751 \\
$\quad$ index & 10.8 & 0.007 & -2.310 & -8.487 \\
Index of ventral flattening & 0.38 & 0.036 & - & - \\
Relative area of dorsal fin & 10.0 & 0.018 & 4.075 & -5.646 \\
Relative area of pectoral fin & 29.1 & 0.008 & -9.063 & -5.646 \\
Pectoral fin aspect ratio & 14.1 & 0.003 & -5.770 & 11.613 \\
Relative area of caudal fin & 10.9 & 0.009 & 6.615 & 6.346 \\
Relative head length & 11.7 & 0.021 & - & - \\
Relative eye position & 0.5 & 0.021 & - & - \\
Relative mouth width & 0.7 & 0.018 & - & - \\
Relative mouth height & 13.0 & 0.006 & - & - \\
Mouth orientation & & & & \\
\hline
\end{tabular}

1998; Ferraris, 2003; Schaefer, 2003).

Clearly the group in question is joined in the morphospace by sharing morphological similarities that are inherited from an exclusive common ancestor (Fig. 8), and are an unequivocal example of ecomorphological divergence between closely related taxa (see Cody \& Mooney, 1978). Separation of Hisonotus sp. from H. garmani and Harttia sp. in the dendrogram of ecomorphological relationships (Fig. 3) is probably related to the different microhabitat exploited by Hisonotus sp. (the surface area of submerged parts of the marginal vegetation versus the similar microhabitats occupied by $H$. garmani and Harttia sp., the rocky bottom of the deeper and faster flowing riffles areas; Casatti \& Castro, 1998). When ecomorphologically compared with Hypostomus garmani, Harttia sp. is supposedly very able to exploit the areas with stronger current, due to its extremely depressed body and relatively long caudal peduncle (see "index of ventral flattening" and "relative caudal peduncle length" above). Indeed, that is exactly what we found in our studied riffles, where adult Harttia sp. specimens were found in areas where almost all other fish species were unable to inhabit continuously due to very strong current.

General considerations. In the evolutionary sense, organisms are historical entities and their use of different environments reflects the historical and phylogenetic components causally related to their behavior and morphology (Brooks \& McLennan, 1991). Since natural selection acts upon morphotypes that are able to maintain themselves in an environment and exploit it, it is assumed that environments with similar physiographies will have fish faunas with similar behavioral and morphological adaptive responses (Winemiller, 1991). Thus, application of the ecomorphological approach to other 


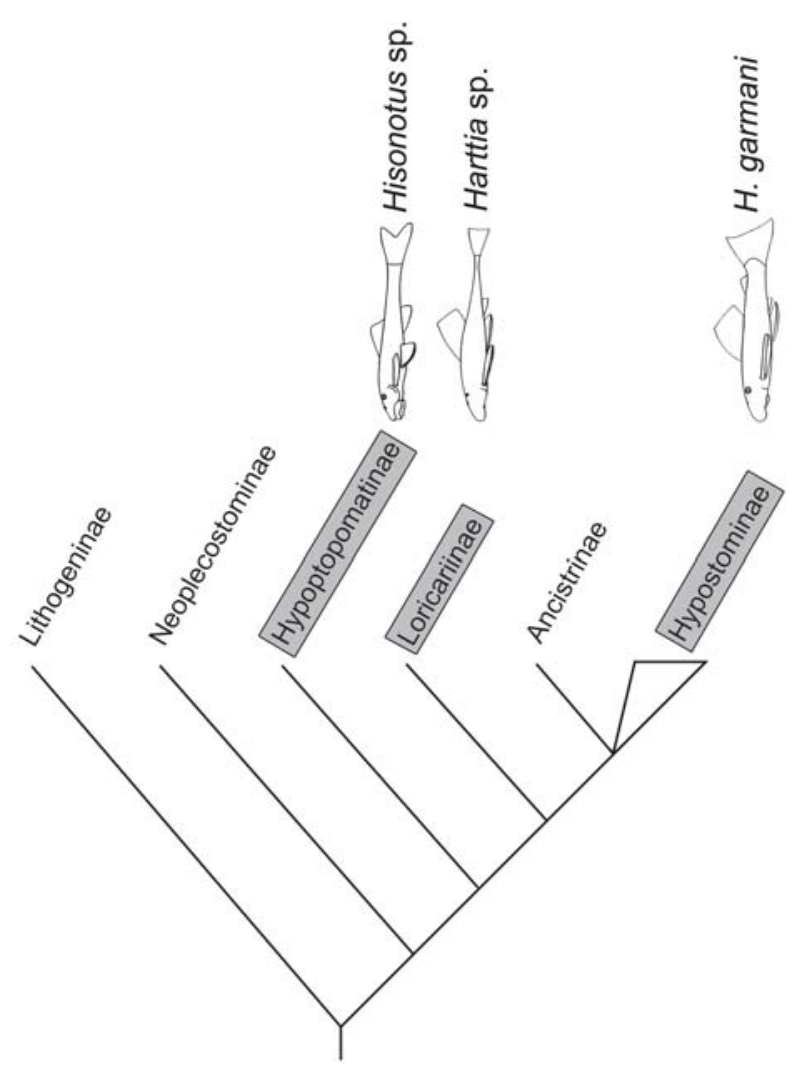

Fig. 8. Cladogram of traditionally accepted phylogenetic relationships among Loricariidae subfamilies (modified from de Pinna, 1988: 304), showing the phylogenetic position of the studied loricariid species, an example of ecomorphological adaptive divergence in the studied riffles. According to Armbruster (2004), Ancistrinae is currently considered a distinct tribe within Hypostominae.

riffle environments could be an excellent exercise to test this hypothesis.

Casatti \& Castro (1998) classified the same studied riffles fishes into omnivores, larvivores, algivores (here called periphytivores) and insectivore-piscivore. The composition of the nektonic, nektobenthic, and benthic ecomorphological groups found in this study partially agrees with the classification of Casatti \& Castro (1998), probably because these categories reflect more than just feeding strategies. They are apparently much more strongly correlated with different morphological strategies causally connected with the need to remain stationary and move around in a strong current than to just feeding by itself. In fact, the complete congruence between the three larger ecomorphological groups identified in the present analysis with the observed guilds of spatial occupation formed by the same species is indeed strong evidence in favor of the proposed predictive value of the ecomorphological hypothesis (Douglas \& Matthews, 1992; Motta $\&$ Kotrschal, 1992).

In addition, we believe that the apparent lack of correlation between diet and morphology does not necessarily point to a weakness in the predictive capacity of ecomorphology, but in reality only to the absence, in our analysis, of attributes associated with oral morphology that have real and refined discriminatory capacity (i.e. teeth morphology and dentary bone shape).

Like other studies conducted in the past (Motta \& Kotrschal, 1992; Winemiller et al., 1995; Motta et al., 1995), we strongly believe that the integration of phylogenetic information and ecomorphological analyses is the only way to objectively identify cases of morphological and adaptive convergence and divergence, allowing for the comprehension of larger evolutionary patterns within the communities (PeresNeto, 1999), like the very clear and unequivocal cases of external morphological convergence between the Characidiinae and Parodontidae and of morphological divergence between Loricariidae species detected in this study.

Finally, through the confrontation between our ecomorphological results with our previously obtained ecological data of the fish species in their environment, we sincerely hope to have been able to provide a valuable and successful test of the predictive values of the ecomorphological hypothesis.

\section{Acknowledgements}

We are very grateful to Hertz F. dos Santos for helping with the field work and with figures 1, 4-8; Alexandre Kemenes for helping with the field work; Rosana Tidon for helping with initial statistical assistance; Ivan Sazima and Virgínia S. Uieda for giving suggestions in several steps of this study; Geraldo M. Rodrigues for allowing us to conduct the field work in his land property; Fernando Z. Gibran and Rodrigo L. Moura for helping with statistical software; Fernando Z. Gibran, Pedro R. Peres-Neto, Marcel R. Cavallaro and Marcelo R. de Carvalho for giving important suggestions on various drafts of this manuscript. This study has benefited by grants from FAPESP (Fundação de Amparo à Pesquisa do Estado de São Paulo, grants number 94/0881-4, 94/4153-3, 96/3286-5, 96/ 7126-2, 97/13150-6, 98/5072-8, 01/0602-3,00/01919-8, 01/133407) and PRONEX (FINEP/CNPq n $\left.{ }^{\circ} 661058 / 1997-2\right)$. RMCC receives a grant from CNPQ (\# 301309/91-4).

\section{Literature Cited}

Allan, J. D. 1995. Stream ecology: structure and function of running waters. Dordrecht, Kluger Academic Publishers, 388p.

Armbruster, J. W. 2004. Phylogenetic relationships of the suckermouth armoured catfishes (Loricariidae) with emphasis on the Hypostominae and Ancistrinae. Zoological Journal of the Linnean Society, 141: 1-80.

Balon, E. K., S. S. Crawford \& A. Lelek. 1986. Fish communities of the upper Danube River (Germany, Austria) prior to the new Rhein-Main-Donau connection. Environmental Biology of Fishes, 154: 242-271.

Beaumord, A. C. \& M. Petrere. 1994. Fish communities of Manso River, Chapada dos Guimarães, MT, Brazil. Acta Biologica Venezuelica, 152: 21-35. 
Bockmann, F. A. 1998. Análise filogenética da família Heptapteridae (Teleostei, Ostariophysi, Siluriformes) e redefinição de seus gêneros. Unpublished Ph.D. Dissertation, Universidade de São Paulo, São Paulo. 599p.

Bockmann, F. A. \& G. M. Guazzelli. 2003. Family Heptapteridae (heptapterids). Pp. 406-431. In: Reis, R. E., S. O. Kullander \& C. J. Ferraris, Jr. (Eds.). Check list of the freshwater fishes of South and Central America. Porto Alegre, Edipucrs, 729p.

Brooks, D. R. \& D. A. McLennan. 1991. Phylogeny, ecology and behavior. Chicago, University of Chicago Press, 434p.

Buckup, P. A. 1993. Review of the characidiin fishes (Teleostei: Characiformes), with descriptions of four new genera and ten new species. Ichthyological Explorations of Freshwaters, 4: 97-154.

Buckup, P. A. 1998. Relationships of the Characidiinae and phylogeny of Characiform fishes (Teleostei: Ostariophysi). Pp. 123-144. In: Malabarba, L. R., R. E. Reis, R. P. Vari, Z. M. S. Lucena \& C. A. S Lucena (Eds.). Phylogeny and classification of neotropical fishes. Porto Alegre, Edipurs, 603p.

Buckup, P. A. 2003. Family Crenuchidae (South American darters). Pp. 87-95. In: Reis, R. E., S. O. Kullander \& C. J. Ferraris, Jr. (Eds.). Check list of the freshwater fishes of South and Central America. Porto Alegre, Edipucrs, 729p.

Casatti, L. \& R. M. C. Castro. 1998. A fish community of the São Francisco River headwater riffles, southeastern Brazil. Ichthyological Exploration of Freshwaters, 9: 229-242.

Castro, R. M. C. \& R. P. Vari. 2003. Family Prochilodontidae (flannel mouth characiforms). Pp. 65-70. In: Reis, R. E., S. O. Kullander \& C. J. Ferraris, Jr. (Eds.). Check list of the freshwater fishes of South and Central America. Porto Alegre, Edipucrs, 729p.

Castro, R. M. C. \& R. P. Vari. 2004. Detritivores of the South American fish family Prochilodontidae (Teleostei: Ostariophysi: Characiformes): a phylogenetic and revisionary study. Smithsonian Contributions to Zoology, 622: 1-189.

Cody, M. L. \& H. A. Mooney. 1978. Convergence versus nonconvergence in Mediterranean-climate ecosystems. Annual Review of Ecology and Systematics, 1978: 265-321.

Douglas, M. E. \& W. J. Matthews. 1992. Does morphology predict ecology? Hypothesis testing within a freshwater fish assemblage. Oikos, 65: 213-224.

Ferraris, C. J. Jr. 2003. Subfamily Loricariinae (armored catfishes). Pp. 330-350. In: Reis, R. E., S. O. Kullander \& C. J. Ferraris, Jr. (Eds.). Check list of the freshwater fishes of South and Central America. Porto Alegre, Edipucrs, 729p.

Fink, S. V. \& W. L. Fink. 1981. Interrelationships of the ostariophysan fishes (Teleostei). Zoological Journal of the Linnean Society, 72: 297-353.

Gatz Jr., A. J. 1979a. Ecological morphology of freshwater stream fishes. Tulane Studies in Zoology and Botany, 21: 91-124.

Gatz Jr., A. J. 1979b. Community organization in fishes as indicated by morphological features. Ecology, 60: 711-718.

Gosline, W. A. 1971. Functional morphology and classification of teleostean fishes. Honolulu, University Press of Hawaii, 208p.

Hora, S. L. 1930. Ecology, bionomics and evolution of the torrential fauna, with special reference to the organs of attachment. Philosophical Transactions of the Royal Society of London, 28: 171-282.

Hynes, H. B. N. 1970. The ecology of running waters. New Jersey, The Blackburn Press, 555p.

Hugueny, B. \& M. Pouilly. 1999. Morphological correlates of diet in an assemblage of West African freshwater fishes. Journal of Fish Biology, 54: 1310-1325.
Karr, J. R. \& F. C. James. 1975. Eco-morphological configurations and convergent evolution in species and communities. Pp. 258291. In: Cody, M. L. \& J. M. Diamond (Eds.). Ecology and evolution of communities. Cambridge, The Belknap Press of Harvard University, 545p.

Lima, F. C. T., L. R. Malabarba, P. A. Buckup, J. F. P. Silva, R. P. Vari, A. Harold, R. Benine, O. T. Oyakawa, C. S. Pavanelli, N. A. Menezes, C. A. S. Lucena, M. C. S. L. Malabarba, Z. M. S. Lucena, R. E. Reis, F. Langeani, L. Cassati, V. A. Bertaco, C. Moreira \& P. H. F. Lucinda . 2003. Genera incertae sedis in Characidae. Pp. 106-169. In: Reis, R. E., S. O. Kullander \& C. J. Ferraris, Jr. (Eds.). Check list of the freshwater fishes of South and Central America. Porto Alegre, Edipucrs, 729p.

Lincoln, R. J., G. A. Boxshall \& P. F. Clark. 1995. Diccionario de ecología, evolución y taxonomía. Mexico, Fondo de Cultura Económica, 488p.

Mahon, R. 1984. Divergent structure in fish taxocenes of north temperate stream. Canadian Journal of Fisheries and Aquatic Sciences, 41: 330-350.

Malabarba, L.R. \& S. H. Weitzman. 2003. Description of a new genus with six new species from southern Brazil, Uruguay and Argentina, with a discussion of a putative characid clade (Teleostei: Characiformes: Characidae). Comunicações do Museu de Ciências e Tecnologia da PUCRS, Série Zoologia, 16(1): 67-151.

Malabarba, L. R., R. E. Reis, R.P. Vari, Z. M. S. Lucena \& C. A. S Lucena (Eds.). 1998. Phylogeny and classification of neotropical fishes. Porto Alegre, Edipucrs, 603p.

Mantel, N. A. 1967. The detection of disease clustering and a generalized regression approach. Cancer Research, 27: 209-220.

McCune, B. \& M. J. Mefford. 1999. PC-ORD. Multivariate analysis of ecological data, version 4. Gleneden Beach, MjM Software Design, 237p.

Motta, P. J. \& K. M. Kotrschal. 1992. Correlative, experimental and comparative evolutionary approaches in ecomorphology. Netherlands Journal of Zoology, 42: 400-415.

Motta, P. J., K. B. Clifton, P. Hernandez \& B. T. Eggold. 1995. Ecomorphological correlates in ten species of subtropical seagrass fishes: diet and microhabitat utilization. Environmental Biology of Fishes, 44: 37-60.

Mullaney Jr., M. D. \& L. D. Gale. 1996. Ecomorphological relationships in ontogeny: anatomy and diet in gag, Mycteroperca microlepis (Pisces: Serranidae). Copeia, 1996: 167-180.

Pavanelli, C. S. 2003. Family Parodontidae (parodontids). Pp. 4650. In: Reis, R. E., S. O. Kullander \& C. J. Ferraris, Jr. (Eds.). Check list of the freshwater fishes of South and Central America. Porto Alegre, Edipucrs, 729p.

Peres-Neto, P. R. 1999. Alguns métodos e estudos em ecomorfologia de peixes de riachos. Pp. 209-236. In Caramaschi, E. P., R. Mazzoni \& P. R. Peres-Neto (Eds.). Ecologia de peixes de riachos. Rio de Janeiro, Oecologia Brasiliensis, volume VI, 260p.

Piet, G. J. 1998. Ecomorphology of a size-structured tropical freshwater fish community. Environmental Biology of Fishes, 51: 67-86.

de Pinna, M. C. C. 1998. Phylogenetic relationships of Neotropical Siluriformes (Teleostei: Ostariophysi): historical overview and synthesis of hypotheses. Pp. 279-330. In: Malabarba, L. R., R. E. Reis, R. P. Vari, Z. M. S. Lucena \& C. A. S Lucena (Eds.). Phylogeny and classification of neotropical fishes. Porto Alegre, Edipurs, 603p.

Reilly, S. M. \& P. C. Wainwright. 1994. Conclusion: ecological morphology and the power of integration. Pp. 339-354. In: Wainwright, P. C. \& S. M. Reilly (Eds.). Ecological morphology: interative organismal biology. Chicago, University of Chicago Press, 367p. 
Reis, R. E., S. O. Kullander \& C. J. Ferraris, Jr. (Eds.). 2003. Check list of the freshwater fishes of South and Central America. Porto Alegre, Edipucrs, 729p.

Roberts, T. R. 1974. Osteology and classification of the neotropical characoid fishes of the families Hemiodontidae (including Anodontinae) and Parodontidae. Bulletin of Museum of Comparative Zoology, 146: 411-472.

Rohlf, F. J. 2000. NTSYS 2.1: numerical taxonomic and multivariate analysis system. New York, Exeter Software.

Schaefer, S. A. 2003. Subfamily Hypoptopomatinae (armored catfishes). Pp. 321-329. In: Reis, R. E., S. O. Kullander \& C. J. Ferraris, Jr. (Eds.). Check list of the freshwater fishes of South and Central America. Porto Alegre, Edipucrs, 729p.

Vogel, S. 1981. Life in moving fluids. New Jersey, Princeton University Press, 353p.

Watson, D. J. \& E. K. Balon. 1984. Ecomorphological analysis of fish taxocenes in rainforest streams of northern Borneo. Journal of Fish Biology, 25: 371-384.

Webb, P. W. 1977. Effects of median-fin amputation on fast-start performance of rainbown trout (Salmo gairdneri). Journal of Experimental Biology, 68: 123-135.
Weber, C. 2003. Subfamily Hypostominae (armored catfishes). Pp. 351-372. In: Reis, R. E., S. O. Kullander \& C. J. Ferraris, Jr. (Eds.). Check list of the freshwater fishes of South and Central America. Porto Alegre, Edipucrs, 729p.

Weitzman, S. H. \& L. R. Malabarba. 1998. Perspectives about the phylogeny and classification of the Characidae (Teleostei: Characiformes). Pp. 161-170. In: Malabarba, L. R., R. E. Reis, R. P. Vari, Z. M. S. Lucena \& C. A. S Lucena (Eds.). Phylogeny and classification of Neotropical fishes. Porto Alegre, Edipurs, 603p.

Wikramanayake, E. D. 1990. Ecomorphology and biogeography of a tropical stream fish assemblage: evolution of assemblage structure. Ecology, 71: 1756-1764.

Winemiller, K. O. 1991. Ecomorphological diversification in lowland freshwater fish assemblages from five biotic regions. Ecological Monographs, 614: 343-365.

Winemiller, K. O., L. C. Kelso-Winemiller \& A. L. Brenkert. 1995. Ecomorphological diversification and convergence in fluvial cichlid fishes. Environmental Biology of Fishes, 44: 235-261.

Received August 2005 Accepted March 2006 